\title{
The Development of Product Archaeology as a Platform for Contextualizing Engineering Design
}

\author{
Prof. Kemper Lewis, University at Buffalo, SUNY \\ Deborah A. Moore-Russo Ph.D., University at Buffalo, SUNY
}

Prior to joining the Graduate School of Education at the University at Buffalo, Dr. Moore-Russo taught in a Department of Mathematics for thirteen years. Her primary research interests include spatial visualization, communication, and reasoning.

\section{Dr. Gul E. Okudan Kremer, Pennsylvania State University, University Park}

Dr. Gül E. Okudan Kremer is an associate professor of Engineering and Industrial Engineering at Pennsylvania State University. Her research focuses on decision analysis and design theory applied to improvement of products and systems. She has co-authored over 200 peer-reviewed papers to date and received several best paper awards. She has been also a National Research Council-US AFRL Summer Faculty Fellow of the Human Effectiveness Directorate for 2002, 2003 and 2004, and a Fulbright Scholar (2010-2011).

Dr. Conrad Tucker, Pennsylvania State University, University Park

Prof. Timothy W. Simpson, Pennsylvania State University, University Park

Dr. Sarah E Zappe, Pennsylvania State University, University Park

Dr. Sarah E. Zappe is director of Assessment and Instructional Support in the Leonhard Center for the Enhancement of Engineering Education at Penn State University. In her current position, Dr. Zappe is responsible for supporting curricular assessment and developing instructional support programs for faculty in the College of Engineering. In her research role, Dr. Zappe is interested in the integration of creativity into the engineering curriculum, innovation, and entrepreneurship. Dr. Zappe holds a doctorate in Educational Psychology specializing in applied testing and measurement. Her measurement interests include the development of instruments to measure the engineering professional skills and using qualitative data to enhance the response process validity of tests and instruments.

Dr. Ann F. McKenna, Arizona State University, Polytechnic campus

Dr. Ann F. McKenna is chair and associate professor in the Department of Engineering in the College of Technology and Innovation at Arizona State University (ASU). Prior to joining ASU she served as a program officer at the National Science Foundation in the Division of Undergraduate Education and was on the faculty in the Department of Mechanical Engineering and Segal Design Institute at Northwestern University. Dr. McKenna received her B.S. and M.S. degrees in Mechanical Engineering from Drexel University and her Ph.D. from the University of California at Berkeley. Dr. McKenna also serves as a senior associate editor for the Journal of Engineering Education.

\section{Dr. Adam R Carberry, Arizona State University}

Dr. Adam R. Carberry is an assistant professor at Arizona State University in the College of Technology \& Innovation's Department of Engineering. He earned a B.S. in Materials Science Engineering from Alfred University, and received his M.S. and Ph.D., both from Tufts University, in Chemistry and Engineering Education respectively. Dr. Carberry was previously an employee of the Tufts' Center for Engineering Education \& Outreach and manager of the Student Teacher Outreach Mentorship Program (STOMP).

Prof. Wei Chen, Northwestern University

Dr. David W. Gatchell, Northwestern University 
Dr. David W. Gatchell is a clinical associate professor of biomedical engineering and mechanical engineering at Northwestern University. In addition, he is director of the Manufacturing and Design Engineering (MaDE) Program within the Segal Design Institute. Prior to joining NU, David was a research professor and instructor in the Biomedical Engineering Department at the Illinois Institute of Technology. He holds a Ph.D. in Biomedical Engineering from Boston University and an A.B. in Physics from Bowdoin College.

\section{Dr. Steven B. Shooter, Bucknell University}

Dr. Steve Shooter is a professor of Mechanical Engineering at Bucknell University where he has taught for eighteen years. He teaches classes such as senior design, exploring innovation, mechanical design, and mechatronics. His research is in information management in design, managing innovation and robotics. As a registered professional engineer in Pennsylvania he has consulted with dozens of companies on new product ventures and production infrastructure.

\section{Dr. Marie C Paretti, Virginia Tech}

Dr. Marie C. Paretti is an associate professor of Engineering Education at Virginia Tech where she codirects the Virginia Tech Engineering Communications Center (VTECC). Her research focuses on communication and teamwork in engineering, design education, and engineering identity. She was awarded a CAREER grant from NSF to study expert teaching practices in capstone design courses nationwide, and is co-PI on NSF. Her work includes studies on the teaching and learning of communication, the effects of curriculum on design cognition, the effects of differing design pedagogies on retention and motivation, the dynamics of cross-disciplinary collaboration in both academic and industry design environments, and gender and identity in engineering.

\section{Dr. Lisa D. McNair, Virginia Tech}

Dr. Lisa DuPree McNair is an associate professor of Engineering Education at Virginia Tech where she also serves as assistant department head of Graduate Education and co-director of the VT Engineering Communication Center (VTECC). She received her Ph.D. in Linguistics from the University of Chicago and an M.A. and B.A. in English from the University of Georgia. Her research interests include interdisciplinary collaboration, design education, communication studies, identity theory and reflective practice. Projects supported by the National Science Foundation include interdisciplinary pedagogy for pervasive computing design; writing across the curriculum in Statics courses; as well as a National Science Foundation CAREER award to explore the use of e-portfolios for graduate students to promote professional identity and reflective practice. Her teaching emphasizes the roles of engineers as communicators and educators, the foundations and evolution of the engineering education discipline, assessment methods, and evaluating communication in engineering.

\section{Dr. Christopher B. Williams, Virginia Tech}




\title{
The Development of Product Archaeology as a Platform for Contextualizing Engineering Design
}

\begin{abstract}
Our long-term objective is to institutionalize and sustain contextual engineering education through product archaeology. Many engineering departments struggle to meet "the broad education necessary to understand the impact of engineering solutions in a global, economic, environmental, and societal context" (Outcome $h$ ) that is required for ABET. As a result, engineering students receive meaningful contextual experiences in piecemeal fashion and graduate with a lack of concrete competencies that bridge knowledge and practice in the global world in which they will live and work. By considering products as designed artifacts with a history rooted in their development, our product archaeology framework combines concepts from archaeology with advances in cyber-enhanced product dissection to implement pedagogical innovations that address the significant educational gap. In this paper, we focus on developing a sustainable and scalable foundation to support novel approaches aimed at educating engineering students to understand the global, economic, environmental, and societal context and impact of engineering solutions. We present our vision for this contextual development and present some initial results from the network of institutions in our NSF TUES-funded project.
\end{abstract}

\section{Contextual Engineering Education: A Problem and an Opportunity}

Engineers in the U.S. face tremendous challenges that include globalization of technical labor, economic turmoil, environmental resource limitations, and the increasingly blurred lines between the social and technical aspects of design. For over a decade, the NAE, NAS, NSF, and ABET have identified engineering education as a principal site for inculcating future engineers with new competencies to thrive in a globalized society. At the same time, they lamented about the "disconnect between the system of engineering education and the practice of engineering" that accelerating global challenges have only exacerbated [1].

Since 1996 the ABET Outcomes Assessment Criteria have offered a set of guidelines to assure that engineers are equipped to succeed and lead in this new world [2]. Among the most vital of these criteria is Outcome h: "the broad education necessary to understand the impact of engineering solutions in a global, economic, environmental, and societal context". Properly understood, Outcome h goes far beyond contextual awareness. It provides the bond between virtually all other ABET outcomes, linking the profession's traditional strengths in scientific knowledge (Outcome a) with design (Outcomes b and c), multidisciplinary teamwork (Outcome $\mathrm{d}$ ), and knowledge of contemporary issues (Outcome $\mathrm{j}$ ). Outcome $\mathrm{h}$ is doubly important for engineering education because such global, economic, environmental, and societal issues have become critical for preparing, engaging, and retaining the nation's best students [3-4]. Developing innovative strategies to teach effectively the skills necessary to understand GSEE context in engineering is not only a national need, but one of international significance. For instance, the UK is stressing engineering education to develop solutions to the "local, social, economic, political, cultural, and environmental context" [5], and China is training engineers to "adapt to changing economic conditions" and "create and explore the new global society" [6]. The work presented in this paper aims to help the U.S. keep up with related educational reforms around the world and re-establish its lead in effectively educating the world's engineers. 
Despite its importance, engineering departments struggle to achieve Outcome h. For instance, at Trinity College, a first-year design course is used to assess every ABET outcome except Outcomes $h$ and i [7]. At Purdue, involvement in extracurricular activities were used to assess each of the ABET outcomes; however, the authors were not able to make any conclusions for Outcome h, noting the need for "further analysis" of this outcome [8]. Briedis [9] notes that the assessment of Outcome h was "less straightforward" than the other professional outcomes, and a new course had to be developed to address this outcome directly. However, most departments do not have the flexibility or room to develop a new course specifically to address any single ABET outcome, much less Outcome $h$. In an already packed engineering curriculum, then, most departments ascribe the development of contextual expertise to an early cornerstone or later capstone design experience, or, alternatively, relegate the task to humanities and social science electives that rarely are integrated with the technical dimensions of design [10]. Consequently, engineering students receive meaningful contextual experiences in piecemeal fashion and graduate with a lack of concrete competencies that bridge knowledge and practice in the global world in which they will live and work.

In an effort to address this significant educational gap, we have formalized a novel pedagogical framework called product archaeology [11] that transforms product dissection activities by prompting students to consider products as designed artifacts with a history rooted in their development. With an "archaeological mindset," students approach product dissection with the task of evaluating and understanding a product's (and its designers') global, societal, economic and environmental context and impact. These hands-on, inductive learning activities require students to move beyond rote knowledge to hone their engineering judgment, analytical decision-making, and critical thinking. This pedagogical framework thus provides students with formal activities to think more broadly about their professional roles as engineers.

\section{Product Archaeology Framework}

Product archaeology combines product dissection and cyberinfrastructure in novel ways to help integrate context - global, societal, economic, and environmental - into engineering courses [11]. Product dissection has a long and rich history of pedagogical innovation dating primarily back to Prof. Sheri Sheppard's Mechanical Dissection course at Stanford [12-13]. Initial developments were in response to a general agreement by U.S. industry, engineering societies, and government that there had been a decline in the quality of undergraduate engineering education over the previous two decades [14-15]. The result was a strong push towards providing both intellectual and physical activities (such as dissection) to anchor the knowledge and practice of engineering in the minds of students [16-17]. Product dissection was successful in achieving this for several reasons. First, it helps couple engineering principles with significant visual feedback [18] and increase awareness of the design process [19]. Dissection also gives students early exposure to functional products and processes, and introducing such experiences early in the students' academic careers has been shown to increase motivation and retention [20]. Such "learning by doing" activities encourage the development of curiosity, proficiency and manual dexterity, three desirable traits of an engineer [21]. Product dissection activities spread around the world as a community emerged around the development and propagation of these activities [17-18,20-26]. These activities have since evolved to all levels of undergraduate 
education (see Figure 1a) as they migrated from one university to the next. For instance, the power drill dissection activity used at Stanford [13] was adopted at Penn State [17] for sophomores and juniors, migrated to Virginia Tech for freshmen [27], and was recently adapted at Northwestern for use in a senior design course [28].

Unfortunately, most product dissection activities only emphasize the technical aspects of products (e.g., form, function, fabrication) [29]. While there are exceptions (e.g., dissection of single-use cameras to explore recycling and reuse [17]), most activities miss opportunities to explore the wide range of non-technical issues that can influence product development. As such, product dissection alone fails to provide "the broad education necessary to understand the impact of engineering solutions in a global, economic, environmental, and societal context".

Product archaeology was born to address these shortcomings of product dissection. The term product archaeology was initially coined by Ulrich and Pearson [30] as the process of dissecting and analyzing a physical product to assess the design attributes that drive cost. Shooter and his colleagues advanced the archaeological aspects of dissection by combining excavation (literally "digging in the sand to find parts") with a WebQuest they developed to enhance middle school students' awareness of and competency in engineering [31]. More recently, we formally defined product archaeology as the process of reconstructing the lifecycle of a product-the customer requirements, design specifications, and manufacturing processes used to produce it-to understand the decisions that led to its development [11]. There is a module on product archaeology in a recent engineering textbook as well [32].

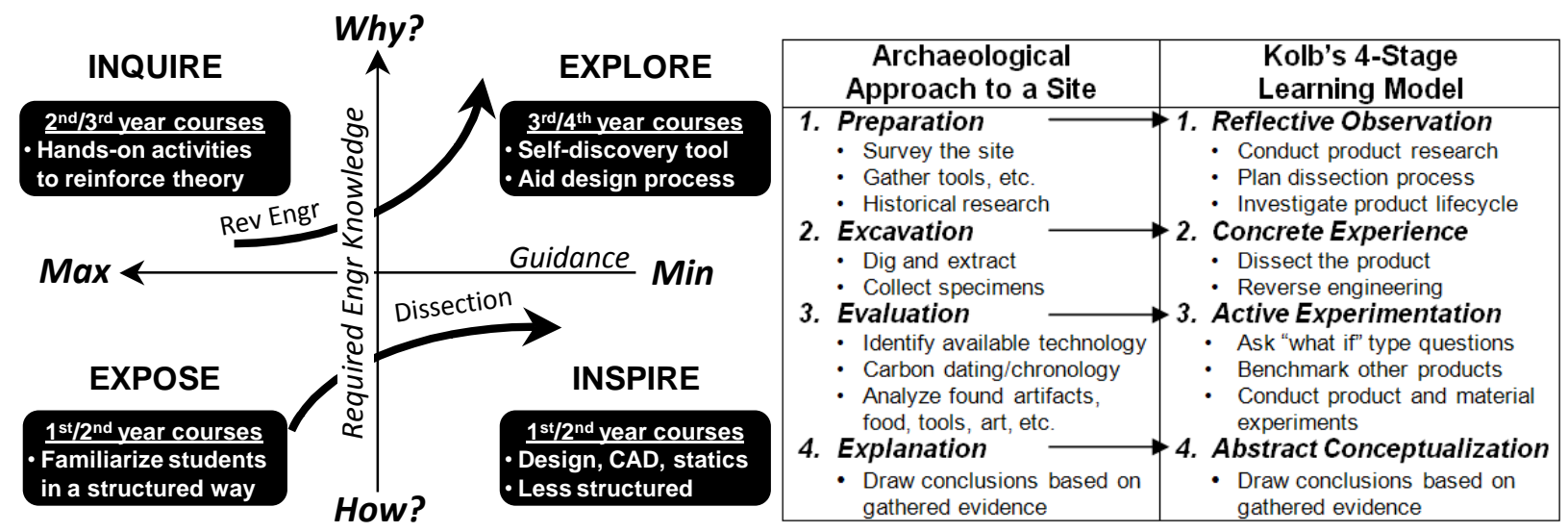

(a) Classifying dissection-based activities [33] (b) Mapping Kolb's Model to Archaeology [11]

Figure 1. Key Components of Our Product Archaeology Framework

To create our product archaeology framework, we mapped Kolb's four-stage learning model [34] to the four phases of archaeology [35]: (1) Preparation, (2) Excavation, (3) Evaluation, (4) Explanation, as shown in Figure 1b. The four keywords from Outcome h (i.e., global, societal, economic, environmental) are then used as triggers to develop questions pertaining to a specific product, usage, and impact using the template shown in Table 1. During the preparation phase, students reflect on what they know about the factors that impact the design of the particular product and postulate responses to questions about its design. The excavation activities lead to concrete experiences where students can physically dissect the product and perform appropriate research to develop well-reasoned answers to specific design-related questions. The evaluation 
phase provides opportunities for students to actively experiment and abstract meaning from their research and concrete dissection experiences. Finally, they articulate their findings during the explanation phase to describe the global, societal, economic, and environmental impact of the product.

Table 1. Template for Developing Product Archaeology Exercises

\begin{tabular}{|c|c|c|}
\hline Stage & $\begin{array}{l}\text { Outcome h } \\
\text { Addressed }\end{array}$ & $\begin{array}{c}\text { Kolb's } \\
\text { Learning Style } \\
\end{array}$ \\
\hline \multicolumn{3}{|c|}{ 1) Preparation: Based on a description of the artifact, address the following issues } \\
\hline $\begin{array}{l}\text { Describe the purpose of the product, how it works, the intended global } \\
\text { market segments, and how cultural needs are addressed with the } \\
\text { product. }\end{array}$ & Global & \multirow{4}{*}{$\begin{array}{l}\text { Reflective } \\
\text { Observation }\end{array}$} \\
\hline $\begin{array}{l}\text { What were the economic conditions at the time this product was } \\
\text { designed and manufactured and how are economic issues reflected in } \\
\text { the product's design? }\end{array}$ & Economic & \\
\hline $\begin{array}{l}\text { What were the planned environmental impacts of this product and } \\
\text { what were the environmental factors engineers had to consider in the } \\
\text { design of the product? }\end{array}$ & Environmental & \\
\hline $\begin{array}{l}\text { What was the planned impact of the product on the culture and } \\
\text { customer base? }\end{array}$ & Societal & \\
\hline \multicolumn{3}{|c|}{ 2) Excavation: Using the artifact and associated artifact-inspired information, perform the following tasks } \\
\hline $\begin{array}{l}\text { Observe how people with different cultures and demographics use the } \\
\text { product and then describe the functions that the product fulfills. }\end{array}$ & Global/Societal & \multirow{4}{*}{$\begin{array}{l}\text { Concrete } \\
\text { Experience }\end{array}$} \\
\hline $\begin{array}{l}\text { Dissect the product, noting each step, tools used, and the } \\
\text { ease/difficulty involved. }\end{array}$ & Societal/Economic & \\
\hline $\begin{array}{l}\text { Determine the material type and manufacturing process for each } \\
\text { component. }\end{array}$ & Economic/Environmental & \\
\hline $\begin{array}{l}\text { Determine the primary function of each major component or group of } \\
\text { components, noting how its structural form helps fulfill its function. }\end{array}$ & Global/Societal & \\
\hline \multicolumn{3}{|c|}{ 3) Evaluation: Based on your excavation process, address the following issues } \\
\hline $\begin{array}{l}\text { What are the intended global markets and how are cultural needs } \\
\text { addressed? }\end{array}$ & Global & \multirow{4}{*}{$\begin{array}{c}\text { Active } \\
\text { Experimentation }\end{array}$} \\
\hline $\begin{array}{l}\text { What were the economic conditions at the time this product was } \\
\text { designed and manufactured, and what did the competitive landscape } \\
\text { look like? }\end{array}$ & Economic & \\
\hline $\begin{array}{l}\text { What were the actual environmental impacts of this product and what } \\
\text { were the environmental factors engineers had to consider in the design } \\
\text { of the product? }\end{array}$ & Environmental & \\
\hline $\begin{array}{l}\text { What was the actual impact of the product on the culture and customer } \\
\text { base? }\end{array}$ & Societal & \\
\hline \multicolumn{3}{|c|}{ 4) Explanation: Address the following implementation issues, considering current and future conditions } \\
\hline $\begin{array}{l}\text { How does the current product line address global market needs? How } \\
\text { could the company address these issues better in their future global } \\
\text { product lines? }\end{array}$ & Global & \multirow{4}{*}{$\begin{array}{c}\text { Abstract } \\
\text { Conceptualization }\end{array}$} \\
\hline $\begin{array}{l}\text { Given current economic conditions, what could engineers at the } \\
\text { company do to enhance the economic impact of the product on the } \\
\text { company? }\end{array}$ & Economic & \\
\hline $\begin{array}{l}\text { How could the company reduce the cradle-to-cradle environmental } \\
\text { impact in future products and product lines? }\end{array}$ & Environmental & \\
\hline $\begin{array}{l}\text { How could the company address social use issues such as safety, } \\
\text { ergonomics, product use experiences, and lifestyle impact better in } \\
\text { future products? }\end{array}$ & Societal & \\
\hline
\end{tabular}


The descriptive nature of our framework provides the flexibility to create hands-on, inductive learning activities for all levels of undergraduate education. We have used our framework to expose freshmen in their introductory design courses to these contextual factors [36], inspire sophomores and make juniors inquire in their engineering electives [37-38], and help seniors explore during their capstone projects [39-40]. Product archaeology represents a low cost, natural extension of product dissection and related hands-on activities that many faculty members are already using. Its flexibility lowers barriers to entry as we heard from participants in our product archaeology workshop [41], and they appear to exhibit the same "stickiness" [42] that product dissection does.

\section{Product Archaeology Implementation and Assessment}

In the most recent multi-university implementation (fall 2012 semester), three universities exercised product archaeology modules and teaching strategies. Various assessment tools were used relative to the style, level, and coverage of each course. This section presents a look at each of the implementations and the results that were available at the time of the writing of this paper.

\subsection{Senior Level Design Methods Course: University at Buffalo - SUNY}

The senior design course, Design Process and Methods, is a required upper undergraduate course with an annual initial enrollment of approximately 180 students. MAE451 is a lecture-only course, focusing on teaching the fundamental theories of a design process, starting from problem clarification to product support. The design process representing the core of the semester activities is shown in Figure 2. Half of the course grade is based on individual homework, a final exam, and a design portfolio. The other half of the grade is based on group project work.

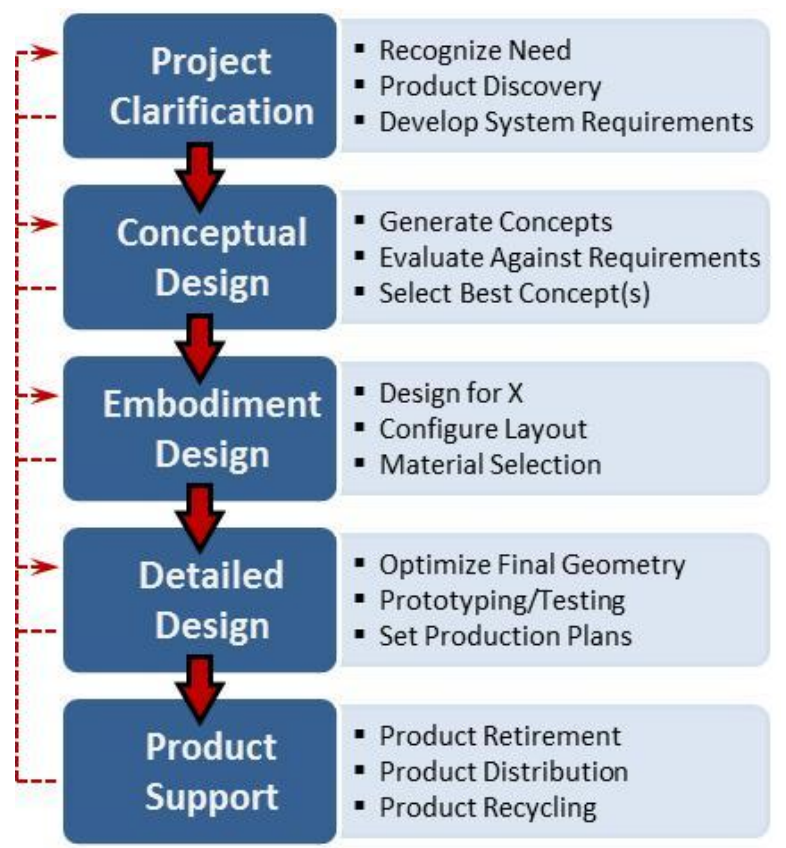

Figure 2. Design Process 
The groups engage in three month-long design projects developed specifically to address GSEE in large-scale global design challenges. In the fall of 2012, these challenges were:

1) Designing an approach for coping with man-made disasters that manage the technical, global, societal, economic, and environmental issues associated with both the disaster and the proposed approach.

2) Designing a method, product, system, or process to shape potentially harmful and abusive human behavior by addressing all of the technical, global, societal, economic, and environmental issues.

3) Design a system or process to help a local, national, or international community reduce its environmental footprint through one or more avenues, managing the technical, global, societal, economic, and environmental issues associated with the problem.

As a result, the student groups had to "dig" to uncover design problems in each project challenge category. The pedagogical focus is on the explanation phase of the PA framework, although in the process of designing and drawing conclusions, the students must perform tasks and experience opportunities related to the other three phases: preparation, excavation, and evaluation.

In addition, the student groups were immersed in a series of "product digs" throughout the semester, administered on the course facebook page (http://www.facebook.com/pages/Mae451University-at-Buffalo/266642943347409?ref=hl), as shown in Figure 3. The learning preferences of today's "Net Generation" students require innovative approaches for in-class engagement [43]. We have developed this type of "dig" leveraging social media and to mimic the excavation stage of archaeology. In these digs, clues from various products are posted one at a time, mirroring archaeological dig processes where artifacts are found sequentially. The students are challenged, like archaeologists, to find relationships between the clues, piecing them together until a larger system is revealed.

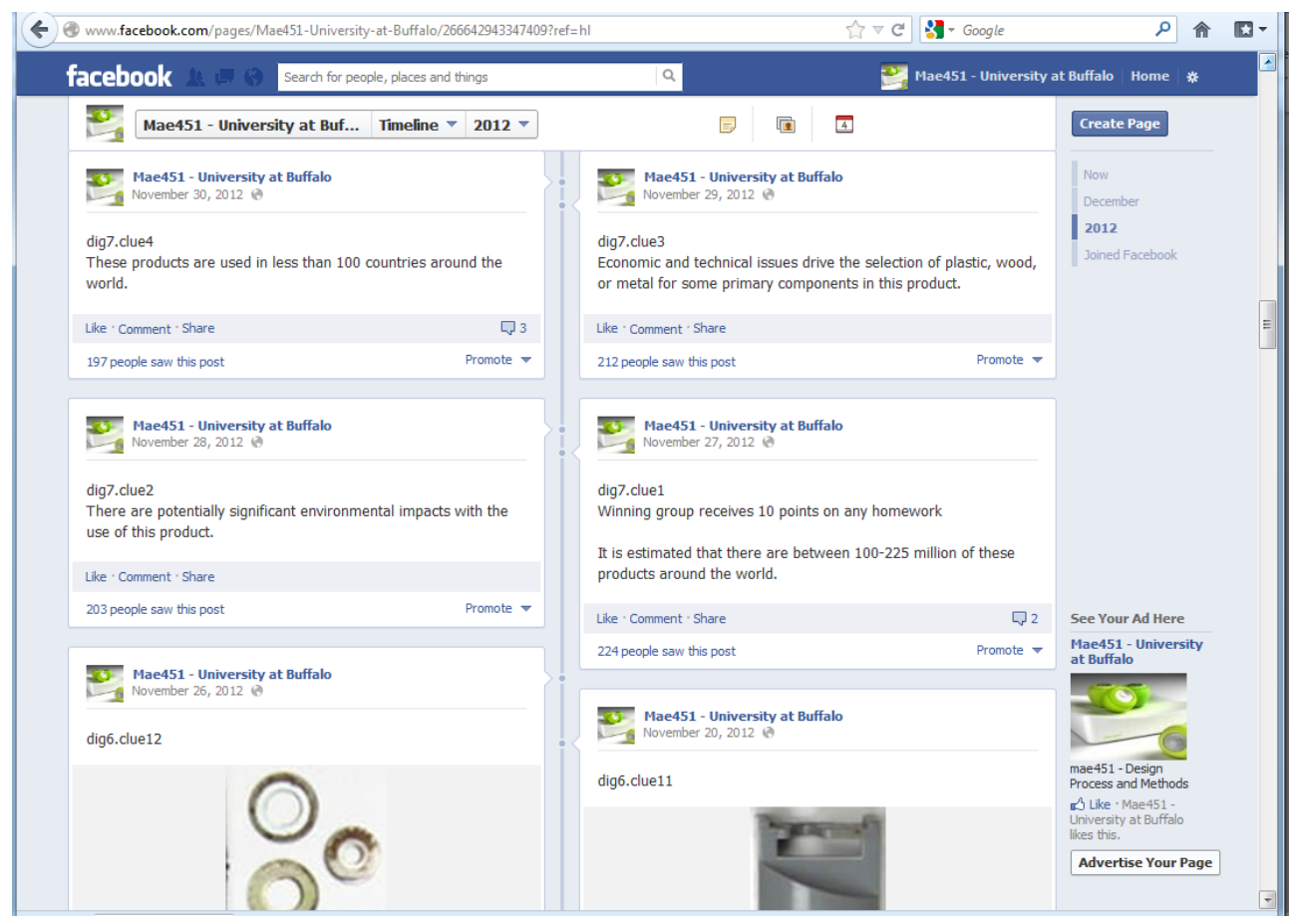

Figure 3. Course Facebook Page 
In Table 2, one particular dig used in the fall 2012 semester (dig 7) is shown to illustrate the types of clues that are given to the class once a day. Clues for other digs in the course included:

- photographs of particular components,

- schematics of particular components,

- names or descriptions of components,

- a fact regarding the social, global, economic, or environmental history of the product,

- a short description of the economic, environment, global, or social conditions that were present when the product was released that influenced its design and/or manufacturing.

Whether visual or textual, the clues revealed either technical, global, social, economic, and/or environmental issues in the design of the product.

Table 2. Dig 7, Fall 2012

\begin{tabular}{|c|c|}
\hline Clue 1 & $\begin{array}{l}\text { It is estimated that there are between } 100-225 \text { million of these } \\
\text { products around the world. }\end{array}$ \\
\hline Clue 2 & $\begin{array}{l}\text { There are potentially significant environmental impacts with the use } \\
\text { of this product. }\end{array}$ \\
\hline Clue 3 & $\begin{array}{l}\text { Economic and technical issues drive the selection of plastic, wood, or } \\
\text { metal for some primary components in this product. }\end{array}$ \\
\hline Clue 4 & These products are used in less than 100 countries around the world. \\
\hline Clue 5 & Egypt leads the world in the current use of this product. \\
\hline Clue 6 & The product is currently in use in the darker shaded countries \\
\hline
\end{tabular}

Clue 7 The darker countries have banned the use of this product.

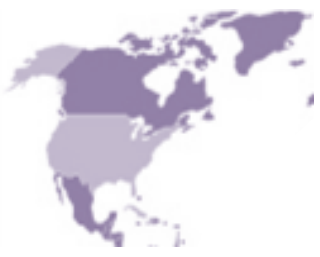

Clue 8 Approximately half of these products around the world are in use; the other half are not being used yet.

\section{Landmines}

Student groups were given one guess per dig and the first group to guess the product was awarded bonus points on a homework or project. Wrong answers eliminated groups from the "dig", and the winning group received bonus points. This created a competitive tension in the class between waiting for more clues to be "unearthed" and being the first to get the right answer. 
Assessment: The assessment instruments used in the course including pre- and post-tests, and a self-reported skill survey. In this paper, we report on the results from the pre- and post-tests, as they provide an excellent snapshot of the impact of product archaeology on the student learning related to the GSEE factors.

All participants in the study were enrolled in the senior Design Process and Methods course. In the semester of the study (fall 2012) there were 185 students enrolled. From this group 173 students took the pretest and 164 took the posttest. Students were asked to use the last four digits of their social security number and their initials as their code names. The research team was able to match 152 of the code names from the pretests and posttests. Of the 152 students, for which repeated measures were available, there were 134 males, 12 females, and the rest did not report their genders. There were 148 seniors and 4 juniors in the group. Of the 152, there were 96 who reported having a mechanical engineering major, 42 who reported having a mechanical and aerospace double major, 12 who reported an aerospace major, and 2 who did not include information regarding the academic major.

The group consisted of 134 US citizens (106 Caucasian, 14 Asian American, 5 African American, 1 Hispanic, 1 Native American, and 7 naturalized citizens), 17 foreign students, and 1 student did not report this information. This information is reported to give some idea of the study participants, but since no group performed significantly different from any other, this information is not used in the data reporting.

Data Collection: All data were gathered via open-ended surveys, representing the pre- and posttests. The surveys were administered on the first and last day of class and students were given 15 minutes to complete the surveys. The surveys consisted of participant demographic information and two items, both of which are listed below. All data were subsequently compiled and analyzed by an external evaluator.

You have been charged with designing a new electric power generator as your first task I Item 1 your role as New Product Development Engineer at Honda. List the major modules you will need to design. For each module, list the primary issues or requirements that you thinking will drive the design of function and form.

\section{Item 2 When developing the next power generator you expect to work with engineers, as well as} individuals in the following fields.

Data Coding: Each item was coded as showing evidence (or not) of one of five factors: technical, global, societal, economic, and environmental. These five factors are outlined in Table 3. The sample responses in Table 3 are excerpts from ten different students that are representative of the responses on the survey. Note that many students would list numerous technical details and then include brief notes such as "must also take into account other considerations like cost and environmental impact." Responses like these were coded as addressing both economic and environmental factors in addition to the technical factor. No attempt was made to differentiate in the number of words or space used for a factor, only if the factor was evident in the student's response. 
Table 3. Technical and GSEE Coding

\begin{tabular}{|c|c|c|}
\hline Code & Relates to. & Sample responses \\
\hline Technical & $\begin{array}{l}\text { Traditional engineering science parameters and } \\
\text { functional issues including thermodynamics, } \\
\text { statics, fluid dynamics, solid mechanics, machine } \\
\text { design, heat transfer, etc. }\end{array}$ & $\begin{array}{l}\text { - Rotor: size requirements, \# of (copper } \\
\text { most likely) windings, \# of coils per turn, } \\
\text { and shaft operating spin speed. } \\
\text { - Engine: Hp output, shaft position } \\
\text { (horizontal/vertical), exhaust location, } \\
\text { size/position of fuel tank, governed speed } \\
\text { of engine. }\end{array}$ \\
\hline Global & $\begin{array}{l}\text { Issues related to global market needs including the } \\
\text { intended global market segments, and cultural } \\
\text { needs related to global geography, customs, and } \\
\text { traditions. }\end{array}$ & $\begin{array}{l}\text { - need to know if it will be used in the U.S. } \\
\text { or abroad. } \\
\text { - electrical socket outlet depends on [the] } \\
\text { geographic location }\end{array}$ \\
\hline Societal & $\begin{array}{l}\text { Issues related to social use of the product including } \\
\text { safety, ergonomics, use experiences, and lifestyle } \\
\text { impact. }\end{array}$ & $\begin{array}{l}\text { - ergonomics ... simple/easy to use } \\
\text { - need to consider the customer's needs and } \\
\quad \text { desires... must be aesthetically appealing }\end{array}$ \\
\hline Economic & $\begin{array}{l}\text { Issues related to the economic and competitive } \\
\text { conditions both at the time the product was } \\
\text { designed and manufactured, and current economic } \\
\text { conditions that could impact of the product's } \\
\text { success. }\end{array}$ & $\begin{array}{l}\text { - must be cost effective so consumers can } \\
\text { afford it } \\
\text { - materials and manufacturing process need } \\
\text { to be cost effective }\end{array}$ \\
\hline Environmental & $\begin{array}{l}\text { Issues related to the planned and actual } \\
\text { environmental impact of the product and the } \\
\text { environmental factors engineers had to consider in } \\
\text { the design of the product and in future products. }\end{array}$ & $\begin{array}{l}\text { - need to consider the environmental effects } \\
\text { and noise pollution } \\
\text { - to be green should consider possible } \\
\text { leakage and emissions }\end{array}$ \\
\hline
\end{tabular}

Note that when a response was vague or could have been interpreted in multiple manners, it was not coded. For example, when a person responded "location" without additional explanation to Item 1, it was not coded since it could have meant that the individual was thinking of global issues related to different cultures, or technical issues related to the products physical surroundings and elements to which the product would be exposed, or environmental issues related to the impact the product's noise or emissions might have, etc.

Data Analysis and Results: In addition to descriptive statistics, McNemar's Test, which involves nonparametric statistics used on repeated measures nominal data, was employed. A two-tail test was used to determine if the marginal proportions were significantly different from each other for any one of the five factors from the pretest to the posttest. Table 4 and Table 5 respectively display the frequency and relative frequencies for student responses showing evidence of each of the five factors on Items 1 and 2 with their significance levels when appropriate. Each of the five factors were noted more in the students' responses to the posttest for Item 1 than their responses to the pretest for this item, with statistically significant differences for the global, societal, economic, and environmental factors in particular. For Item 2 all five factors were evidenced at statistically significant rates on the posttest over the pretest. 
Table 4. Frequency and Relative Frequency of Technical and GSEE Factors Evidenced on Item $1(n=152)$

\begin{tabular}{lcc}
\hline \hline \multicolumn{1}{c}{ Factor } & Pretest: & Posttest: \\
& Count (\% of Matched Pairs) & Count (\% of Matched Pairs) \\
\hline Technical & $148(80 \%)$ & $152(82 \%)$ \\
Global** & $5(3 \%)$ & $19(10 \%)$ \\
Societal $* * *$ & $46(25 \%)$ & $102(55 \%)$ \\
Economic $* * *$ & $36(19 \%)$ & $71(38 \%)$ \\
Environmental* & $46(25 \%)$ & $64(35 \%)$ \\
\hline \hline
\end{tabular}

Significance (two-tailed) indicated as follows: $* p<.05, * * p<.01, * * * p<.001$

Table 5. Frequency and Relative Frequency of Technical and GSEE Factors Evidenced on Item $2(n=152)$

\begin{tabular}{lcc}
\hline \hline \multicolumn{1}{c}{ Factor } & $\begin{array}{c}\text { Pretest: } \\
\text { Count (\% of Matched Pairs) }\end{array}$ & $\begin{array}{c}\text { Posttest: } \\
\text { Count (\% of Matched Pairs) }\end{array}$ \\
\hline Technical* & $114(62 \%)$ & $131(71 \%)$ \\
Global $^{* * *}$ & $6(3 \%)$ & $41(22 \%)$ \\
Societal $^{* * *}$ & $63(34 \%)$ & $114(62 \%)$ \\
Economic*** & $68(37 \%)$ & $92(50 \%)$ \\
Environmental $* *$ & $17(9 \%)$ & $37(20 \%)$ \\
\hline \hline Significance (two-tailed) indicated as follows: $* p<.05, * * p<.01, * * * p<.001$
\end{tabular}

In addition, the number of the five possible factors used in responses on the survey (including responses to both Items 1 and 2) was considered. The students' responses provided evidence that they considered more factors on the posttest $(\mu=3.59, \sigma=0.97)$ than they did on the pretest $(\mu=$ $2.59, \sigma=1.06$ ). Since the data were not normally distributed for either the pretest or the posttest, a Wilcoxon Signed Ranks Test was used. Using this nondirectional (two-tailed) significance test, it was determined that the course elicited a statistically significant change in the number of factors considered in survey responses $(\mathrm{Z}=-7.77, p<.001)$. This was in line with the findings that the median number of factors evidenced in student responses to the survey on the pretest was 3 , while on the posttest it was 4 .

\subsection{Freshman Level Introduction to Engineering Course: Penn State University}

During the fall 2012 semester, product archeology concepts have been introduced as part of the dissection to redesign project in the freshman Introduction to Engineering course (EDSGN 100). As opposed to the University at Buffalo implementation, this project lasted only about six weeks (of a 15-week semester). As part of this project, students were asked to incorporate the product archeology concept to the external search activities of their design process, during which they have accumulated and analyzed information to help with the subsequent redesign activities. During this project, two course sections of the course focused on the redesign of an electric toothbrush, while a third section focused on rice cookers. Project requirements asked students to use product archeology concepts during their designs, and document their work on this as part of their design reports. 
Assessment: Students were provided an optional test question (worth 17/102 points) to respond to the following questions:

1) Briefly explain what product archeology is, and how and for what purpose it can be used in support of designing, or redesigning a product.

2) Consider your team's implementation of product archeology. Please circle from the options below on which GSEE issue(s) your product archeology work related to (You can circle more than one):
a. Global
b. Economic
c. Environmental
d. Societal

3) For one of the options you have selected above, briefly explain your findings. List three components (or sub-assemblies) that have been impacted by the GSEE issues over time.

From the 59 students who took the test, 55 of them responded to the product archeology question.

Data Collection: As part of our data analysis, we evaluated the responses to this test question; while we have evaluated the design reports in general, we will further link the understanding level of the concept to the effectiveness of the implementation in design projects. As for the responses to the questions provided above, the first seeks to document the level of comprehension of this concept. Responses to the question 2 document the various facets of the GSEE issues as perceived by students in relation to their projects. Responses to question 3 document students' recall of their product archeology implementation along with their association of the GSEE focused component/sub-assembly level improvements.

Data Analysis and Results: The responses of these students to explain the product archeology concept have been mostly very good. The students found the relation of their PA activity to the following GSEE issues: a) $20 \%$ of the students related the PA activity to global issues, b) $56 \%$ of the students related the PA activity to economic issues, c) $56 \%$ of the students related the PA activity to environmental issues, and d) $65 \%$ of the students related the PA activity to societal issues. Two sample responses are provided in Figure 4.

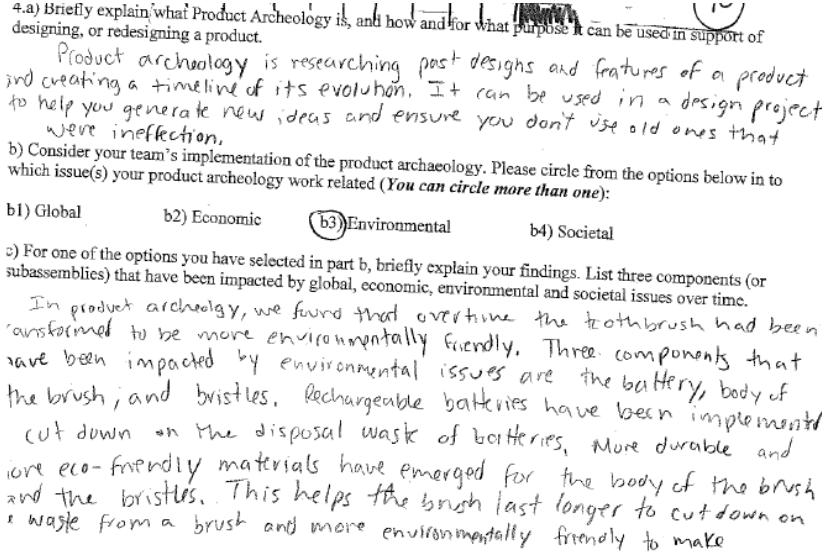

a. Sample 1

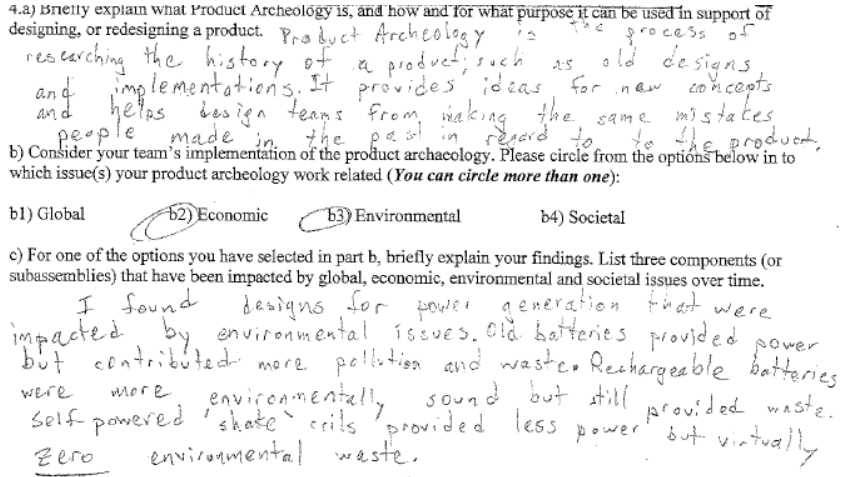

b. Sample 2

\section{Figure 4. Sample Product Archaeology Responses}

\section{Conclusions}

While students are globally connected via the internet, routinely exposed to environmental marketing campaigns, living in trying economic conditions, and defined by diverse social 
networks, this is not translating to an understanding of how these issues will impact the engineered solutions of tomorrow. Indeed, students today are more aware of the global, social, economic, and environmental problems all over the world than ever before but they still struggle to find efficient pathways of connecting their skills, passions, and knowledge to help solve these problems in a timely fashion. In this paper, we present a comprehensive paradigm, product archaeology, that can be implemented across engineering curricula to address the global, social, economic, and environmental issues in developing engineered solutions.

Product archaeology enriches the limited exposure that students currently get to many of these topics and provide opportunities to demonstrate how engineering "makes a difference" in the world [3], which has been shown by the National Academies to be more likely to attract young people to engineering than emphasizing the challenge of math and science skills [44]. Also, in an effort to make engineering exciting again [45], product archeology promotes active and collaborative learning and enriching educational experiences, two of five critical benchmarks related to student learning as found in a recent study by the National Survey of Student Engagement [46]. Finally, our framework creates a rich archaeological analogy that provides relevant context and authentic experience [47-49] for engineering students while addressing many of "the human factors dimensions of working across disciplines, cultures, and institutions using technology-mediated collaborative tools" [50]. Most importantly, we have shown in this paper and others that product archaeology activities are effective for student learning [36-39,51].

In addition, we present some results from recent implementations that demonstrate the impact on students' understanding of the global, social, economic, and environmental issues and particularly on student fulfillment of ABET outcome (h). Our current work and future plans include the following:

- We are curating "proven" product archaeology materials (i.e., activities, rubrics, and assessment) for dissemination. By "proven", we mean well-structured product archaeology activities that have been shown to be effective in the classroom, have been successfully used by multiple faculty, and have transferred across universities. These materials will be "packaged" in numerous formats (e.g., DOC, PPT, PDF) and made available through our primary portal, www.productarchaeology.org. We will also transition proven materials from our institutional partners, which continue to be refined online in Wiki format (http://gicl.cs.drexel.edu/wiki/CIBER-U).

- The packaging of materials will include many types of media files that will require efficient searchable policies and effective digital representation. Our team will work with the Science and Engineering Communities of Practice in the DataNet Federation Consortium (DFC) to deploy a new approach for implementing data management infrastructure for data-driven science and engineering that transcends technology and social networks through federation-based sustainability models. The DFC to create new services and policies specific to engineering data types (e.g., to facilitate data migration, integrity checking, provenance, access rights) in support of cyber-enabled needs of product archaeology [52] and help to define a generic infrastructure that can be leveraged across both science and engineering.

- Our short-term deployment plan includes multiple engineering courses across seven institutional partners and our long-term plan includes expanding the deployment to over 
fifteen institutions with more emerging annually. Some partners will serve as material developers while others will serve as material adopters.

\section{References Cited:}

[1] National Academy of Engineering, 2005, Educating the Engineer of 2020: Adapting Engineering Education to the New Century, The National Academies Press, Washington, D.C.

[2] Engineering Accreditation Commission, 1999, Criteria for Accrediting Engineering Programs, ABET, Baltimore, MD, http://www.abet.org/.

[3] National Academy of Engineering, 2008, Changing the Conversation: Messages for Improving Public Understanding of Engineering, The National Academies Press, Washington, D.C.

[4] Sheppard, S. D., Macatangay, K., Colby, A. and Sullivan, W. M., 2009, Educating Engineers: Designing for the Future of the Field, Jossey-Bass, San Francisco, CA.

[5] Bourn, D. and Neal, I., 2008, The Global Engineer: Incorporating Global Skills Within UK Higher Education of Engineers, Development Education Research Centre. London, England, Institute of Education at the University of London.

[6] Chen, M., 2006, "How a Chinese University Trans Engineers to Meet with Challenges Today and Tomorrow," Asia-Pacific Journal of Cooperative Education, 7(1), 1-6.

[7] Ahlgren, D. J., 2001, "Fire-fighting Robots and First-year Engineering Design: Trinity College Experience," Proceedings of the ASEE/IEEE Frontiers in Education Conference, Reno, NV, Paper No. S2E-1.

[8] Dalrymple, O. and Evangelou, D., 2006, "The Role of Extracurricular Activities in the Education of Engineers," International Conference on Engineering Education, San Juan, Puerto Rico, Paper No. T4K-24.

[9] Briedis, D., 2002, "Developing Effective Assessment of Student Professional Outcomes," International Journal of Engineering Education, 18(2), 208-216.

[10] Biney, P., 2007, "Assessing ABET Outcomes Using Capstone Design Courses," ASEE Annual Conference \& Exposition, Paper No. AC2007-1556.

[11] Lewis, K., Moore-Russo, D., Ashour, O., Kremer, G., Simpson, T. W., Neumeyer, X., McKenna, A. and Chen, W., 2011, "Teaching the Global, Economic, Environmental, and Societal Foundations of Engineering Design through Product Archaeology," ASEE Annual Conference \& Exhibition, Vancouver, British Columbia, Canada, June 26-29, ASEE-1149.

[12] Sheppard, S. D., 1992, "Mechanical Dissection: An Experience in How Things Work," Proceedings of the Engineering Education Conference: Curriculum Innovation \& Integration, Santa Barbara, CA.

[13] Sheppard, S., 1992, "Dissection as a Learning Tool," Proceedings of the IEEE Frontiers in Education Conference, Nashville, TN, IEEE.

[14] Fincher, C., 1986, "Trends and Issues in Curricular Development in Higher Education," Handbook of Theory and Research, Smart, J., Agathon, New York, 2, 275-308.

[15] Nicolai, L. M., 1995, "Designing a Better Engineer," Aerospace America, 30(4), 30-33.

[16] Brereton, M. F., 1998, The Role of Hardware in Learning Engineering Fundamentals: An Empirical Study of Engineering Design and Dissection Activity, Mechanical Engineering. Palo Alto, CA, Stanford University.

[17] Lamancusa, J., Torres, M., Kumar, V. and Jorgensen, J., 1996, "Learning Engineering by Product Dissection," ASEE Conference, Washington D.C.

[18] Barr, R., Schmidt, P., Krueger, T. and Twu, C.-Y., 2000, "An Introduction to Engineering Through and Integrated Reverse Engineering and Design Graphics Project," ASEE Journal of Engineering Education, 89(4), 413-418.

[19] Otto, K. N. and Wood, K. L., 2001, Product Design: Techniques in Reverse Engineering and New Product Development, Prentice Hall, Upper Saddle River, NJ. 
[20] Carlson, B., Schoch, P., Kalsher, M. and Racicot, B., 1997, "A Motivational First-Year Electronics Lab Course," ASEE Journal of Engineering Education, 86(4), 357-362.

[21] Beaudoin, D. L. and Ollis, D. F., 1995, "A Product and Process Engineering Laboratory for Freshmen," ASEE Journal of Engineering Education, 84(3), 279-284.

[22] Agogino, A. M., Sheppard, S. and Oladipupo, A., 1992, "Making Connections to Engineering During the First Two Years," 22nd Annual Frontiers in Education Conference, Nashville, TN, IEEE, 563-569.

[23] Lamancusa, J. S., Jorgensen, J. E. and Zayas-Castro, J. L., 1997, "The Learning Factory-A New Approach to Integrating Design and Manufacturing into the Engineering Curriculum," Journal of Engineering Education, 86(2), 103-112.

[24] Felder, R., Beichner, R., Bernold, L., Burniston, E., Dail, P. and Fuller, H., 1997, "Update on IMPEC, An Integrated First-Year Engineering Curriculum at North Carolina State University," Proceedings of ASEE Annual Conference and Exhibition, Milwaukee, WI, June 15-18.

[25] Mickelson, S. K., Jenison, R. and Swanson, N., 1995, "Teaching Engineering Design through Product Dissection," Proceedings of the ASEE Annual Conference and Exhibition, Anaheim, CA.

[26] Demetry, C. and Groccia, J., 1997, "A Comparative Assessment of Students' Experiences in Two Instructional Formats of an Introductory Materials Science Course," ASEE Journal of Engineering Education, 86(3), 203-210.

[27] Goff, R. M. and Gregg, M. H., 1998, "Why Hands-on Design? A First Year Hands-on Design \& Dissection Laboratory," 1998 Industrial Designers Society of America (IDSA) National Design Education Conference, Long Beach, CA.

[28] McKenna, A. F., Chen, W. and Simpson, T. W., 2008, "Exploring the Impact of Virtual and Physical Dissection Activities on Students' Understanding of Engineering Design Principles," ASME Design Engineering Technical Conferences - Design Education Conference, New York, NY, DETC2008/DEC49783.

[29] Ogot, M., Kremer, G., Lamancusa, J. and Simpson, T. W., 2008, "Developing a Framework for Disassemble/Analyze/Assemble (DAA) Activities in Engineering Education," Journal of Design Research, 7(2), 120-135.

[30] Ulrich, K. T. and Pearson, S., 1998, "Assessing the Importance of Design through Product Archaeology," Management Science, 44(3), 352-369.

[31] West, T., Feurstein, A. and Shooter, S., 2008, "Using Cyber-Infrastructure Enhanced Product Dissection to Introduce Engineering to Middle School Students," ASEE International Conference on Engineering Education, Pittsburgh, PA, ASEE Paper No. AC2008-590.

[32] Wickert, J. and Lewis, K., 2013, Introduction to Mechanical Engineering, Cengage Learning, Florence, KY.

[33] Ogot, M. and Kremer, G., 2006, "Developing a Framework for Disassemble/Analyze/Assemble (DAA) Activities in Engineering Education," ASEE Annual Conference \& Exposition, Chicago, IL.

[34] Kolb, D., 1984, Experiential Learning: Experience as the Source of Learning and Development, Prentice Hall, Englewood Cliffs, NJ.

[35] Renfrew, C. and Bahn, P., 2004, Archeology: Theories, Methods, and Practice, Thames \& Hudson, New York.

[36] Devendorf, E., Cormier, P., Moore-Russo, D. and Lewis, K., 2011, "Using Product Archaeology to Integrate Global, Economic, Environmental, and Societal Factors in Introductory Design Education," ASME International Design Technical Conferences - Design Education Conference, Washington, D.C., DETC2011/DEC-48438.

[37] Moore-Russo, D., Grantham, K., Lewis, K., Bateman, S. M., 2010, "Comparing Physical and Cyber-enhanced Product Dissection: An Analysis from Multiple Perspectives," International Journal of Engineering Education, 26(6), 1378-1390.

[38] Simpson, T. W., Okudan, G. E., Ashour, O. and Lewis, K., 2011, "From Product Dissection to Product Archaeology: Exposing Students to Global, Economic, Environmental, and Societal Impact through 
Competitive and Collaborative 'Digs'," ASME International Design Technical Conferences - Design Education Conference, Washington, D.C., DETC2011/DEC-48298.

[39] McKenna, A., Neumeyer, X. and Chen, W., 2011, "Using Product Archaeology to Embed Context in Engineering Design," ASME International Design Technical Conferences - Design Education Conference, Washington, D.C., DETC2011/DEC-48242.

[40] Lewis, K. and Moore-Russo, D., 2011, "Upper Level Engineering Design Instruction Using a Product Archaeology Paradigm," ASME International Design Technical Conferences - Design Education Conference, Washington, D.C., DETC2011/DEC-47933.

[41] Lewis, K., Simpson, T. W., Chen, W., Kremer, G. and McKenna, A., 2010, "From Product Dissection to Product Archaeology: Understanding the Global, Economic, Environmental, and Societal Foundations of Engineering Design," ASME Design Engineering Technical Conferences, Montreal, Quebec, Canada.

[42] Gladwell, M., 2000, The Tipping Point: How Little Things Can Make a Big Difference, Little Brown, New York, NY.

[43] Oblinger, D. G. and Oblinger, J. L., Eds., 2005, Educating the Net Generation, Educause, Boulder, CO.

[44] The National Academies, 2008, "How To Attract Young People To Engineering: 'Make A Difference' Message Is Key," ScienceDaily, DOI: Retrieved January 7, 2013, from http://www.sciencedaily.com/releases/2008/06/080624145221.htm.

[45] Postareff, L., Lindblom-Ylänne, S. and Nevgi, A., 2008, "A Follow-up Study of the Effect of Pedagogical Training on Teaching in Higher Education," Higher Education, 56(1), 29-43.

[46] National Academy of Engineering, 2005, Engineering Research and America's Future: Meeting the Challenges of a Global Economy, The National Academies Press, Washington, D.C.

[47] Penner, D. E., Lehrer, R. and Schauble, L., 1998, "From Physical Models to Biomechanics: A Design-Based Modeling Approach," The Journal of the Learning Sciences, 7(3/4), 429-449.

[48] Puntambekar, S. and Kolodner, J. L., 1998, "The Design Diary: A Tool to Support Students in Learning Science By Design," Proceedings of the 1998 International Conference on the Learning Sciences, 230-236.

[49] Roth, W. M., 1996, "Art and Artifact of Children's Designing: A Situated Cognition Perspective," The Journal of the Learning Sciences, 5(2), 129-166.

[50] Atkins, D. E., Droegemeier, K. K., Feldman, S. I., Garcia-Molina, H., Klein, M. L., Messerschmitt, D. G., Messina, P., Ostriker, J. P. and Wright, M. H., 2003, Revolutionizing Science and Engineering Through Cyberinfrastructure, National Science Foundation, Arlington, VA.

[51] Kang, K., 2011, Using Product Dissection to Expose Engineering Students to Cultural Issues in Product Design, Department of Industrial \& Manufacturing Engineering. University Park, PA, Penn State University. MS Thesis.

[52] Regli, W., Kopena, J. B., Grauer, M., Simpson, T., Stone, R., Lewis, K., Bohm, M., Wilkie, D., Piecyk, M. and Osecki, J., 2010, "Semantics for Digital Engineering Archives Supporting Engineering Design Education," AI Magazine, 31(1), 37-50. 